\title{
Hubungan Beban Kerja Fisik dengan Kejadian Low Back Pain (LBP) pada Kuli Panggul Beras di Pasar Induk Gedebage Bandung
}

\author{
Emilda Hanifa, ${ }^{1}$ Deddy Koesmayadi, ${ }^{2}$ Yuli Susanti ${ }^{3}$ \\ ${ }^{1}$ Program Studi Pendidikan Dokter, ${ }^{2}$ Bagian Anestesi, ${ }^{3}$ Bagian Ilmu Kesehatan Masyarakat \\ Fakultas Kedokteran Universitas Islam Bandung
}

\begin{abstract}
Abstrak
Prevalensi low back pain (LBP) di Indonesia 85-95\% terjadi karena penyebab non-spesifik, di antaranya aktivitas fisik yang berat, mengangkat beban terlalu berat, postur tubuh statis saat bekerja, posisi bekerja, faktor gaya hidup, dan faktor psikologis. Tujuan penelitian ini mengetahui hubungan beban kerja fisik dengan kejadian low back pain (LBP) pada kuli panggul beras di Pasar Induk Gedebage periode Maret 2019. Penelitian ini menggunakan metode analitik observasional dengan pendekatan cross sectional. Subjek penelitian terdiri atas 33 responden. Pengambilan data dilakukan menggunakan kuesioner dan observasi. Hasil penelitian didapatkan bahwa sebagian besar responden mengalami kejadian LBP sebanyak 29 orang. Responden yang memiliki beban kerja fisik dengan beban $33-52 \mathrm{~kg} /$ angkat adalah sebanyak 23 orang, dan kejadian LBP sebanyak 19 orang. Hasil ananisis statistik menunjukkan bahwa tidak terdapat hubungan yang bermakna antara beban kerja fisik dan kejadian low back pain $(\mathrm{p}=0,372)$, namun terdapat faktor lain yang terkait dengan kejadian LBP, di antaranya usia, masa kerja, posisi angkat, dan skala nyeri.
\end{abstract}

Kata kunci: Beban kerja fisik, LBP, kuli panggul

\section{The Relationship of Physical Workload with the Incidence of Low Back Pain (LBP) in Rice Hip Coolies at Pasar Induk Gedebage Bandung}

\begin{abstract}
The prevalence of low back pain (LBP) in Indonesia is about $85-95 \%$, it occurs due to non-specific causes, including heavy physical activity, lifting weights too heavy, static posture at work, working position, lifestyle factors, and psychological factors. The purpose of this study was to determine the relationship of physical workload with the incidence of low back pain (LBP) in rice hip coolies at Pasar Induk Gedebage during March 2019. This research used observational analytic method with cross sectional approach. The research subjects consisted of 33 respondents. Data were collected by using questionnaires and observations. The results showed that the majority of respondents experienced LBP events as many as 29 people. Respondents who had a physical workload with a load of 33-52 $\mathrm{kg} / \mathrm{lift}$ were 23 people, and LBP events were 19 people. Statistical analysis showed that there was no significant relationship between physical workload and the incidence of low back pain $(p=0.372)$. Conclusion, there is no relationship between physical workload and the incidence of low back pain in rice hip coolies at Pasar Induk Gede Bage, but there are other factors associated with LBP events, including age, work period, lifting position, and pain scale.
\end{abstract}

Keywords: Low back pain, physical workload, porters

Received: 8 February 2020; Revised: 15 July 2020; Accepted: 30 July 2020; Published: 31 July 2020

Koresponden: Agnes Aryani Putri, Prodi Pendidikan Sarjana Kedokteran, Fakultas Kedokteran, Universitas Islam Bandung, Jl. Tamansari No. 22, 40116, Kota Bandung, Provinsi Jawa Barat. Telp: (022) 4203368 Fax: 4231213 Ponsel: 085353081998 E-mail: agnesaryaniputri@gmail.com 


\section{Pendahuluan}

Low back pain (LBP) atau nyeri punggung bawah merupakan penyakit muskuloskeletal yang disebabkan oleh kelainan pada otot-otot skeletal. ${ }^{1}$ Nyeri terasa di antara batas bawah tulang rusuk ke-12 sampai ke lipatan bokong, yaitu di daerah lumbal atau lumbosakral serta sering disertai dengan penjalaran nyeri ke arah tungkai dan kaki..,3 Kelainan tersebut disebabkan oleh otot terus menerus menerima paparan berulang berupa beban statis yang menyebabkan kerusakan pada otot, saraf, dan jaringan lain di daerah punggung bagian bawah. ${ }^{1}$

Kejadian LBP paling sering disebabkan oleh penyebab non-spesifik, yaitu pada $85-95 \%$ kasus. ${ }^{4}$ Penyebab LBP non-spesifik 80\% berkaitan dengan pekerjaan yang mengharuskan pekerja itu untuk mengangkat beban saat bekerja..$^{5,6}$ Di lingkungan kerja LBP dapat dipengaruhi oleh beban kerja, kapasitas kerja, dan lingkungan kerja. ${ }^{6}$ Beban kerja merupakan kegiatan yang harus diselesaikan dalam durasi waktu tertentu. Beban kerja terdiri atas beban mental, sosial, dan beban fisik. Beban kerja fisik adalah pekerjaan yang memerlukan energi fisik otot sebagai sumber tenaganya. ${ }^{7}$ Kegiatan mengangkut beban secara manual dengan beban yang berat menyebabkan beban kerja fisik yang tinggi. Berat beban yang diangkat tersebut menyebabkan penekanan pada segmen tulang belakang (L5/S1) yang kemudian mengakibatkan kerusakan lapisan intervertebral disk (elemen yang berada di antara tulang belakang). Kerusakan lapisan tersebut menyebabkan penekanan dan mengiritasi akar saraf sehingga menimbulkan nyeri. Kerusakan lain yang disebabkan oleh berat beban yang diangkat secara terus-menerus adalah kerusakan pada otot, ligamen, dan tendon pada daerah tersebut yang memperparah keluhan nyeri.7,8 Tujuan penelitian mengetahui hubungan beban kerja fisik dengan kejadian low back pain pada kuli panggul beras.

\section{Metode}

Penelitian ini adalah penelitian analitik observasional dengan pendekatan cross sectional terhadap kuli panggul beras di Pasar Induk Gedebage periode Maret 2019 dengan teknik pengambilan sampel menggunakan total sampling. Besar sampel berdasar atas hasil observasi adalah 33. Pengumpulan data dilakukan dengan cara pengukuran, observasi, dan menggunakan kuesioner.

Data yang dikumpulkan meliputi data usia, indeks massa tubuh (IMT), kebiasaan merokok, riwayat pendidikan, masa kerja, posisi angkat, beban fisik, kejadian LBP, dan skala nyeri tiap-tiap responden. Beban kerja fisik dibagi atas 3 kategori: kategori 1 (33$52 \mathrm{~kg} /$ angkut) kategori 2 (53-72 kg/angkut) kategori 3 (73-92 kg/angkut). Data yang telah terkumpul kemudian diolah secara analitik univariat dan bivariat menggunakan chi square test, kemudian disusun dan disajikan dalam bentuk laporan penelitian. Penelitian ini sudah mendapat persetujuan etik oleh Komite Etik Penelitian Kesehatan Fakultas Kedokteran Universitas Islam Bandung dengan nomor : 081/Komite Etik.FK/ IV/2019.

\section{Hasil Penelitian}

Berdasar atas hasil penelitian yang telah dilaksanakan, karakteristik responden berupa usia, riwayat pendidikan, indeks massa tubuh (IMT), kebiasaan merokok, dan masa kerja pada kuli panggul beras di Pasar Induk Gedebage dapat dilihat pada Tabel 1 di bawah ini.

\section{Tabel 1 Karakteristik Responden}

\begin{tabular}{lc}
\hline Karakteristik & $\begin{array}{c}\text { Jumlah } \\
\mathbf{n}=\mathbf{3 3}\end{array}$ \\
\hline Usia (tahun) & \\
$\leq 25$ & 2 \\
$26-35$ & 16 \\
$36-45$ & 14 \\
$>45$ & 1 \\
Pendidikan & \\
SD & 15 \\
SMP & 18 \\
IMT & \\
Underweight & 4 \\
Normal range & 19 \\
Overweight & 10 \\
Kebiasaan merokok & \\
Ya & 31 \\
Tidak & 2 \\
Masa kerja (tahun) & \\
$\quad<5$ & 4 \\
$5-10$ & 22 \\
$>$ 10 & 7 \\
\hline
\end{tabular}

Reponden semua laki-laki terbanyak berusia $26-$ 35 tahun, yaitu 30 dari 33 orang. Responden semua memiliki pendidikan SD dan SMP. Berdasar atas IMT, responden terbanyak memiliki normal range (19 orang) dan overweight (10 orang). Hampir semua responden merokok (31 orang) dengan kerja 5-10 tahun (22 orang).

Beban kerja fisik pada kuli panggul beras di Pasar Induk Gedebage mayoritas dalam kategori 1 (20 orang), sedangkan kategori 2 dan 3 adalah 8 dan 5 orang.

Gambaran kejadian low back pain (LBP) dan skala nyeri pada kuli panggul beras di Pasar Induk Gedebage dapat dilihat pada Tabel 2 di bawah ini.

Tabel 2 Gambaran Kejadian Low Back Pain (LBP) dan Skala Nyeri Kuli Panggul Beras

\begin{tabular}{lc}
\hline Kejadian LBP dan Skala Nyeri & $\begin{array}{c}\text { Jumlah } \\
\text { (n=33) }\end{array}$ \\
\hline Kejadian low back pain (LBP) & 29 \\
Ya & 4 \\
Tidak & \\
Skala nyeri & 2 \\
0 = tidak nyeri & 12 \\
1-3 = nyeri ringan & 17 \\
$4-7$ = nyeri sedang & 2 \\
$8-9=$ nyeri berat & \\
\hline
\end{tabular}


Sebagian besar kuli panggul beras di Pasar Induk Gedebage mengalami kejadian low back pain skala ringan (12 orang) dan skala sedang (17 orang).

Hubungan beban kerja fisik dengan kejadian LBP pada kuli panggul beras di Pasar Induk Gedebage dapat dilihat pada Tabel 3 .

Tabel 3 Hubungan Beban Kerja Fisik dengan Kejadian Low Back Pain (LBP) pada Kuli Panggul Beras di Pasar Induk Gedebage

\begin{tabular}{lccc}
\hline $\begin{array}{c}\text { Beban Kerja } \\
\text { Fisik }\end{array}$ & \multicolumn{2}{c}{ Low Back Pain (LBP) } & Nilai \\
\cline { 2 - 3 } & $\begin{array}{c}\text { Ya } \\
\text { n=29 }\end{array}$ & $\begin{array}{c}\text { Tidak } \\
\mathbf{n}=\mathbf{4}\end{array}$ & p \\
\hline Kategori 1 & 16 & 4 & \\
Kategori 2 & 8 & 0 & 0,228 \\
Kategori 3 & 5 & 0 & \\
\hline
\end{tabular}

*) uji chi-square

Hasil uji chi square tidak terdapat hubungan yang bermakna antara beban kerja fisik dan keluhan low back pain (LBP) pada kuli panggul beras di Pasar Induk Gedebage.

\section{Pembahasan}

Berdasar atas hasil penelitian ini diketahui bahwa sebagian besar kuli panggul beras di Pasar Induk Gedebage dengan beban kerja fisik pada kategori 1 (33-52 kg/angkat). Di lapangan, para kuli panggul bekerja mengangkut beras rerata mencapai 33-92 $\mathrm{kg} / \mathrm{kali}$ angkat. Para kuli panggul bekerja dengan mengangkat beban yang berbeda-beda sesuai dengan kemampuan tubuh tiap-tiap pekerja, ada yang kuat mengangkat hanya 2 karung beras $(50 \mathrm{~kg}$ ) dalam sekali angkat dan ada pula yang mampu mengangkat 3 sampai 4 karung $\left(75^{-100} \mathrm{~kg}\right)$ dalam sekali angkat. Para pekerja memerlukan tenaga yang cukup besar untuk melakukan kegiatan tersebut. Pekerjaan yang menggunakan tenaga besar dapat menyebabkan beban mekanik yang besar pada otot, tendon, ligamen, dan sendi sehingga dapat menyebabkan iritasi, inflamasi, kelelahan dan kerusakan otot serta tendon dan juga jaringan lain. Hal tersebut menjadi salah satu faktor risiko pekerjaan yang dapat menyebabkan LBP. ${ }^{6}$

Hasil penelitian ini menunjukkan tidak terdapat hubungan yang bermakna antara beban kerja fisik dan keluhan LBP pada kuli panggul beras di Pasar Induk Gedebage. Hal ini kemungkinan disebabkan oleh faktor lain seperti jarak yang ditempuh tidak terlalu jauh atau berat beban yang diangkat dapat ditoleransi oleh kekuatan otot pekerja. ${ }^{9,10}$

Faktor lain yang terkait dengan kejadian LBP dipengaruhi oleh beberapa faktor, di antaranya usia, indeks massa tubuh (IMT), masa kerja, kebiasaan merokok, riwayat pendidikan, riwayat penyakit, dan riwayat trauma. Selain itu, LBP juga dipengaruhi oleh beban kerja, kapasitas kerja, dan lingkungan kerja. ${ }^{6}$ Faktor risiko tertinggi yang dapat menyebabkan keluhan LBP adalah beban yang diangkut oleh pekerja. ${ }^{11}$ Petugas kuli panggul beras di Pasar Induk Gedebage bekerja mengangkat beban dalam setiap harinya dapat mencapai 353-2.528 kg tanpa menggunakan alat bantu, hal itu sangat melampaui batas angkat maksimal yang telah ditetapkan dalam Peraturan Menteri Tenaga Kerja, Transmigrasi dan Koperasi No. PER.01/Men/1978. Aktivitas angkat maksimal menurut jenis kelamin yang telah ditetapkan, pekerja laki-laki dewasa (18-6o tahun) memiliki batas angkat maksimal $40 \mathrm{~kg}$ untuk sekali angkat dan $15^{-18} \mathrm{~kg}$ untuk aktivitas angkat yang terus-menerus. ${ }^{12}$ Selain itu, para petugas kuli panggul beras di Pasar Induk Gedebage tidak memperhatikan posisi angkat yang benar sehingga dapat meningkatkan risiko LBP. ${ }^{6}$

Kegiatan mengangkut beban secara manual dengan berat beban yang berat menyebabkan beban kerja fisik meningkat sehingga pekerja memerlukan energi fisik otot yang tinggi sebagai sumber energinya. Berat beban yang diangkat tersebut menyebabkan penekanan pada segmen tulang belakang (L5/S1) yang kemudian mengakibatkan kerusakan lapisan intervertebral disk. Kerusakan lapisan tersebut menyebabkan penekanan dan mengiritasi akar saraf sehingga menimbulkan nyeri. Seiring berjalannya waktu, ketika berat beban tersebut diangkat secara terus-menerus dapat menyebabkan kerusakan pada otot, ligamen, dan tendon pada daerah tersebut yang memperparah keluhan nyeri. ${ }^{7,8}$ Teori tersebut sejalan dengan penelitian yang dilakukan oleh Nurzannah dkk.13 pada tahun 2015 mengenai hubungan faktor risiko dengan nyeri punggung bawah (low back pain) pada tenaga kerja bongkar muat di Pelabuhan Belawan Medan menunjukkan terdapat hubungan bermakna usia, masa kerja, beban kerja, dan sikap kerja dengan kejadian LBP.

Berdasar atas skala nyeri, responden yang mengalami LBP paling banyak berada pada skala 4-7 (nyeri sedang). Hal ini sejalan dengan hasil penelitian oleh kelompok Studi Persatuan Dokter Saraf Seluruh Indonesia (PERDOSSI) pada tahun 2002 bahwa pederita LBP rerata memiliki nilai nyeri pada nyeri sedang sampai berat. Keluhan nyeri otot biasanya tidak terjadi pada orang yang memiliki waktu istirahat yang cukup dalam kesehariannya. Seseorang yang memiliki pekerjaan yang membutuhkan pengeluaran tenaga yang besar, namun tidak memiliki waktu yang cukup untuk istirahat akan meningkatkan risiko keluhan otot. $^{14}$ Keluhan LBP sendiri lebih sering terjadi pada orang yang memiliki ketidakseimbangan antara kemampuan fisik yang dimiliki dan beban pekerjaan yang harus dikerjakan. Para kuli panggul beras memiliki kemampuan fisik dan berat beban angkat yang berbeda-beda, yang sebagian besar berat beban angkat tersebut melebihi kemampuan angkat tiap-tiap pekerja. Keadaan beban kerja terlalu berat melampaui kemampuan fisik yang rendah dapat memperberat keluhan nyeri. ${ }^{15}$

\section{Simpulan}

Beban kerja fisik pada kuli panggul beras di Pasar Induk Gedebage sebagian besar berada pada kategori $1(33-52 \mathrm{~kg} / \mathrm{kali}$ angkat) per hari. Tidak terdapat hubungan berat beban kerja fisik dengan kejadian low back pain (LBP) pada kuli panggul beras di Pasar Induk Gedebage. 


\section{Daftar Pustaka}

1. Kaur K. Prevalensi keluhan low back pain (LBP) pada petani di wilayah kerja UPT Kesmas Payangan Gianyar April 2015. ISM. 2015;5(1):4951.

2. Persatuan Dokter Saraf Indonesia. Standar pelayanan medik Perdossi. Jakarta: Perdossi; 2013.

3. Fizikalnu, Centar Z. low back Pain from definition to diagnosis. National Library of Medicine. 2011;58(2):105-7.

4. Duthey B. Background Paper 6.24 low back pain: priority medicines for Europe and the world. Geneva: WHO; 2013.

5. Susanto N. Faktor-faktor yang berhubungan dengan keluhan nyeri pinggang pada buruh gendong di pasar Bandungan Kabupaten Semarang. J Kes Masyarakat. 2013;2(2):1-5.

6. Andini F. Risk factor in low back pain in Workers. J Majority. 2015;4(1):12-8.

7. Nugroho IA, Marchianti CAN, Hermansyah Y. Pengaruh beban kerja fisik terhadap tingkat disabilitas pasien nyeri punggung bawah di RSD dr. Soebandi Jember. e-journal Pustaka Kesehatan. 2017;5(2):317-8.

8. Nurmianto E. Ergonomi konsep dasar dan aplikasinya. Edisi ke-2. Surabaya: Guna Widya; 2008.
9. Devi TT, Purba IG, Lestari M. Faktor resiko keluhan musculoskeletal disorders (MSDs) pada aktivitas pengangkutan berat di PT Buyung Poetra Pangan Pegayut Ogan Ilir. J Ilmu Kes Masyarakat. 2017;8(2):126-132.

10. Septadina IS, Legiran. Nyeri pinggang dan faktorfaktor risiko yang mempengaruhinya. J Sriwijaya University. 2014;1(1):5-8.

11. Ihsan MZ. Gambaran sikap ergonomi dan proporsi keluhan muskuloskeletal pada tenaga kerja bongkar muat barang Jalan Tanjung Batu Kecamatan Lima Puluh Kota Pekanbaru. JOM FK. 2015;2(2):9-12.

12. Nurzannah, Sinaga M, Salmah U. Hubungan faktor resiko dengan terjadinya nyeri punggung bawah (low back pain) pada tenaga kerja bongkar muat (TKBM) di Pelabuhan Belawan Medan Tahun 2015. J Lingkungan Keselamatan Kerja. 2015;4(1).

13. Nurlis E, Bayhakki, Erika. Pengaruh terapi dingin ice massage terhadap perubahan intensitas nyeri pada penderita low back pain. Jurnal Ners Indonesia. 2012;2(41):185-91.

14. Remon, Utami GT, Dewi AP. Hubungan antara posisi tubuh saat bekerja terhadap kejadian low back pain (LBP) pada petani sawit. J Online Mahasiswa. 2016;2(2):1396-401. 